\title{
Klass, kön och etnicitet i den sociala barnavården
}

\author{
TOMMY LUNDSTRÖM \& MARIE SALLNÄS
}

\begin{abstract}
Denna artikel tar utgångspunkt $i$ ett socialpolitiskt perspektiv och analyserar hur barnavårdsproblem över tid kopplats till klass, kön och etnicitet. Hur har dessa faktorer behandlats i officiella texter om barnavård under 1900talet och hur framstår de i offentlig statistik?
\end{abstract}

\section{Inledning}

Den här artikeln tar sin utgångspunkt i CSA:s 100 årsjubileum som är samtida med den första mer sammanhållna barnavårdslagstiftningen från 1902, lagen om "vanartade och i sedligt avseende försummade barns behandling». På CSA:s kongress år 1906 diskuterades barnens och barnfamiljernas förhållanden och den sociala barnavårdens framtid (CSA, 1906). Flera inlägg har ett för tiden ovanligt tydligt artikulerat socialpolitiskt perspektiv. Några av talarna anvisade sociala reformer som ett sätt att hjälpa exempelvis ensamma mödrar att själva kunna ta hand om sina barn. Läkaren Karolina Widerström föreslog moderskaps-

Tommy Lundström är professor i socialt arbete vid Stockholms universitet. Han forskar bland annat om social barnavård samt det sociala arbetets organisering och metoder.

Marie Sallnäs är universitetslektor i socialt arbete vid Stockholms universitet. Hennes forskning är framförallt inriktad på socialtjänstens placeringar av barn och ungdomar utanför det egna hemmet. penning: „Om en väl ordnad moderskapspenning skulle komma till stånd, vore fosterbarnsfrågan i samma stund så gott som bragt ur världen« (Widerström, 1906, s. 59, se även Isberg, s. 66 och Meyerson, s. 93 i samma volym).

Detta sätt att resonera står i kontrast till den samtida lagstiftningen som var starkt moraliskt präglad och närmast programmatiskt avvisade allt utom individinriktade åtgärder. I 1902 års lag oroade man sig för barn som lärdes upp till tiggeri och lögnaktighet av sina föräldrar, för ungdomar som uppträdde i gäng, som stal och som prostituerade sig, för fäder som tillbringade sin fritid utanför hemmet och för mödrar som inte klarade av att fostra sina barn (Betänkande och förslag angående vanartade och i sedligt avseende försummade barns behandling, 1899, se även Lundström, 1993). Lagstiftningen byggde på en tankefigur som innebar att kön och klass kopplades till specifika moraliska egenskaper. Starkt typifierat handlade det om den omoraliska 
underklassens negativa påverkan på sina barn. Man kan säga att lagen uppmärksammade vissa gruppers utsatta situation och att utsattheten vållade svårigheter $i$ föräldrarollen, men till syvende och sist sågs problemen som en fråga om bristande karaktär och moral hos de enskilda individerna.

Vare sig vid denna tid eller under resten av 1900-talet har barnavården betraktats som en del av välfärdsstaten eller socialpolitiken. Följaktligen har den inte heller analyserats i socialpolitiska termer. Ändå är det uppenbart att det finns klara samband mellan barnavårdsåtgärder och socioekonomiska faktorer. Idag kan detta via olika forskningsrapporter och offentlig statistik avläsas i en kraftig överrepresentation av ensamstående mödrar, socialbidragstagare, arbetslösa och invandrare bland de som har kontakt med barnavården. Det är också ett faktum att andelen barn och ungdomar som varit föremål för barnavårdsinsatser stadigt har minskat sedan 1930-talet, det vill säga under välfärdsstatens framväxt. Under 1990-talet har man - kanske delvis mot bakgrund av försämrade ekonomiska villkor för den offentliga sektorn och ökad stress för barnfamiljer - kunnat observera ökningar $\mathrm{i}$ andelen barn och unga som omhändertas och blir föremål för förebyggande åtgärder av olika slag (Andersson, 1995; Hessle, 1988; Hessle \& Vinnerljung, 1999; Hollander, 1985; Lundström, 2000; Lundström \& Vinnerljung, 2001). Det finns alltså tydliga tecken på att barnavårdsproblem, åtminstone mätt som antal omhändertagna barn, hänger ihop med strukturella faktorer och samhällsförändringar.

I den här artikeln tar vi utgångspunkt i ett socialpolitiskt perspektiv. Syftet är att analysera hur sociala problem kring det uppväxande släktet över tid kopplats till klass, kön och etnicitet - begrepp som i dagens socialpolitiska diskussioner har en helt central roll både i forskning och i politik. Hur har dessa faktorer behandlats i offentligt tryck om social barnavård under de senaste 100 åren, det vill säga sedan Sverige fick sin första barnavårdslagstiftning? Genom att i en omläsning av de historiska texterna fokusera på klass, kön och etnicitet kan vi tydliggöra hur staten genom lagstiftningen mer eller mindre explicit kopplat vissa egenskaper (moraliska, psykologiska) och vissa sociala problem till dessa begrepp. Vi frågar oss också i vilken utsträckning man i officiella texter diskuterat socioekonomiska faktorers betydelse för barns uppväxtförhållanden och sambanden mellan strukturellt betingad utsatthet och barnavårdsåtgärder. Vid sidan av de officiella texterna följer vi också offentlig statistik och några viktiga undersökningar för att se hur "barnavårdspopulationen" enligt dessa källor fördelar sig och vilka förändringar som skett utifrån "våra" tre begrepp. Vi är naturligtvis inte de första med att anlägga ett klass-, köns- och etnicitetsperspektiv på barnavården (se Dahl, 1978; Løkke, 1989; Parton, 1985; Frost \& Stein, 1989; Swift, 1995, för analyser av Norge, Danmark, England och Kanada), men oss veterligen finns ingen undersökning som systematiskt tar sig an det svenska 1900-talet med sådana utgångspunkter.

\section{Att läsa historien baklänges}

Vi diskuterar alltså barnavårdsproblemen historiskt (och i viss mån idag) utifrån ett 
nutida socialpolitiskt perspektiv. Det är ett tänkande som bland annat innebär att beskrivningar av människors livsvillkor och levnadsförhållanden struktureras efter vissa centrala variabler, som klass, kön och etnicitet. Det är en sentida tankefigur att problemgrupper eller målgrupper för samhällets insatser konstitueras utifrån hur deras sociala situation beskrivs på aggregerad nivå. Det är en del av den moderna välfärdsstatens tankesätt att grupper som uppfattas som marginella, behövande eller hotande skall kartläggas, räknas och därefter bli föremål för åtgärder från samhällets sida. Det är naturligtvis viktigt att reflektera över när och varför det överhuvudtaget blir relevant att intressera sig för barnavårdspopulationen ur ett sådant "variabelperspektiv«. När vi granskar barnavården över tid och tar utgångspunkt i klass, kön och etnicitet betyder det att vi applicerar dagens tänkande kring sociala problem på en svunnen tid. Vi läser historien baklänges och lägger ett modernt raster över en dåtida barnavård som verkade $\mathrm{i}$ en annan kontext och i ett annat slags samhälle.

Det finns naturligtvis problem med att använda sig av vår tids begrepp för att förstå och bedöma gårdagen (Meeuwisse \& Swärd, 2002). Vi är väl medvetna om detta och menar att när vi ställer frågor kring hur man i seklets början behandlade klass, kön och etnicitet kan materialet säga oss både något om barnavårdens synsätt och åtgärder och om hur dessa kan förstås i en modern tankeram. En konsekvens av detta är att det inte är möjligt att arbeta med traditionella operationaliseringar av de grundläggande begreppen. Arbetarklass eller fattigdom är knappast detsamma i slutet av 1900-talet som i början och »invandrare» kan betyda olika saker över tid.

De texter vi undersökt utgörs dels av offentligt tryck som förarbeten till lagar och dokument från Socialstyrelsen, vilket inkluderar ett antal undersökningar av barnavårdspopulationens sammansättning, dels av några centrala forskningsrapporter som haft betydelse i diskussionen om vilka de utsatta barnen och familjerna är. Källmaterialet är naturligtvis inte neutralt. Det är myndigheters, beslutsfattares och i någon mån forskares perspektiv på barnavården och de som är föremål för dess åtgärder som vi har studerat.

Med artikelns syfte för ögonen har vi gått igenom de viktigaste förarbetena till den lagstiftning som reglerat den sociala barnavården under 100 år. Det gäller dels de utredningar som föregått de viktigaste ändringarna i lagstiftningen år 1902, 1924, 1960 och 1980, dels några centrala utredningar om fosterbarnsvård och barnhemsvård (för diskussion av källmaterialet se Lundström, 1993 och Sallnäs, 2000). I offentlig statistik har vi försökt följa hur barnavårdens åtgärder i form av omhändertaganden fördelar sig efter klass, kön och etnicitet. Det är endast för omhändertaganden, det vill säga fosterhems- och institutionsplaceringar, som det finns något så när stabil offentlig statistik, varför vi får nöja oss med några viktiga nedslag. Slutligen bygger vi texten på några centrala kvantitativt inriktade undersökningar som analyserar barnavårdspopulationens sammansättning. 


\section{Industriarbetarklassen, vanarten och den sedliga försummelsen}

Vi använder i denna artikel begreppet klass och besläktade ord som fattigdom och social status i en allmän betydelse och avstår medvetet från att definiera dem närmare. Det material vi har tillgång till säger något om hur de grupper som vid olika tidpunkter beskrevs som fattiga, underpriviligerade eller tillhörande arbetarklassen var relaterade till barnavårdsproblemen enligt våra källor. Till skillnad från kön och etnicitet har klass, socialgrupp eller annan form av social tillhörighet aldrig registrerats i den offentliga barnavårdsstatistiken. Det är därför svårt att säga något specifikt om förändringar över tid eller att ens mer exakt uttala sig om hur fattiga familjers överrepresentation i barnavården sett ut. Dessutom har sätten att komma åt klass/socialgrupp eller grad av fattigdom varierat över tid och mellan olika studier. I somliga undersökningar har man sökt klassbestämma de utsatta familjerna och jämfört dem med normalpopulationer. Ett annat vanligt klassrelaterat mått är andelen familjer som erhållit fattigvårdsunderstöd/socialbidrag.

\section{Klass, lag och moral}

När en mer sammanhållen barnavårdslagstiftning introducerades vid förra sekelskiftet var det just den fattiga industriarbetarklassens levnadsförhållanden och förändringar i familjelivet som oroade de styrande (Betänkande och förslag angående vanartade och i sedligt avseende försummade barns behandling, 1899). Dessa förändringar påverkade, enligt utredarna, föräldrarna negativt genom att mödrarna inte fick tid att se efter barnen och genom att fäderna riskerade att hamna i fylleri. Men urbaniseringen kunde också påverka barnen direkt genom att de lockades in $\mathrm{i}$ in i storstadens faror (bettleri, lögnaktighet, kriminalitet osv).

Lagstiftarens tankefigur kan beskrivas på följande vis: Industrialiseringen skapade ett urbant proletariat vars förmåga och vilja att fostra barn kunde sättas $i$ fråga. Det ledde till att barnen lämnades vind för våg, utsatta för stadens frestelser och utan den föräldraauktoritet de behövde. I värsta fall hade barnen föräldrar som direkt lockade dem till dåligheter. För ungdomar oroade man sig för att ett tidigt inträde $\mathrm{i}$ arbetslivet skulle innebära en alltför snabbt utvecklad självständighet (Betänkande och förslag angående minderåriga förbrytares behandling, 1898; Betänkande och förslag angående vanartade och i sedligt avseende försummade barns behandling, 1899; Lundström, 1993). I mer grundläggande mening handlade dock barnavårdsproblem enligt den tidens sätt att tänka inte om fattigdom utan om dålig moral. Det var bristen på moral som var det primära problemet hos arbetarklassen inte bristen på pengar eller andra materiella förutsättningar. Det fanns en djup misstro mot de hemmiljöer och det föräldraskap som fanns i arbetarklassen. Det var här - i de undermåliga och moraliskt tvivelaktiga arbetarklasshemmen - som roten till många samhällsproblem fanns.

Det mycket tydliga moraliskt grundade klasstänkandet som kan identifieras i 1902 år lagstiftning märks inte på samma sätt 
i förarbetena till barnavårdlagarna från 1924 och 1960. Man talar inte längre om arbetarklassens brister som fostrare eller om industrialismens negativa verkningar på de ungas moral. I 1924 år lag hade barnavårdsproblemet omkonstruerats från att huvudsakligen vara ett storstadsproblem inom arbetarklassen till ett problem av mer individrelaterad natur. Med den allmänna rösträtten och socialdemokratins växande inflytanden var det knappast längre möjligt att explicit beskriva arbetarklassens familjer som kollektivt moraliskt undermåliga och potentiellt samhällsfarliga (Westberg, 1906; Proposition 1924:150, s. 39; Fattigvårdslagstiftningskommitténs betänkande nr IV, 1921, del II: Statistiska undersökningar, avdelning $\mathrm{A}$ och $\mathrm{B}$ ).

I den större lagstiftningsreform som gjordes i och med 1960 års barnavårdslag kan man tydligt spåra den under 1920- till 1940-talet framväxande barnpsykiatrins ökande inflytande. I förarbetena till lagen lades mycket liten vikt vid de rådande samhällsförhållandena och de utsatta familjernas sociala position (SOU 1956: 61; Proposition 1960:10; se även Proposition 1942:20, för en första förändring av lagstiftningen i psykologisk/psykiatrisk riktning). Man kan säga att 1960 års lag kodifierade de psykologiska förklaringsmodeller som från 1920-talet började ersätta den tidiga lagstiftningens öppna moralism.

I förarbetena till 1980-talets socialtjänstlagstiftning behandlades de sociala omständigheternas betydelse som problemalstrande faktorer bland annat genom att man betonade vikten av strukturella åtgärder. I socialutredningens principbetänkande fördes en relativt omfattande diskussion om huvuddragen i den socialpolitiska utvecklingen. Man diskuterade också under rubriken "sociala processer" sådant som levnadsnivå, utvecklingen på arbetsmarknaden, urbaniseringen och familjelivets förändringar. Texterna runt socialtjänstreformen präglades av en viss radikalism och ett starkt ifrågasättande av den gamla lagstiftningen. Den nya socialtjänsten skulle vara demokratisk och verka för människors lika levnadsförhållanden, också för barnavårdens mödrar, fäder och unga. I de skrivningar som berör barnavården och vad som orsakar ungas problem och hur de skall lösas, fick dock sådana faktorer som klass och fattigdom knappast en framskjuten position. Snarare är det psykologiska faktorer, relationsproblem i familjen och ungdomars avvikelser som står i fokus (Proposition 1979/80: 1 A.) s. 207; SOU 1974:39 s. 282-283). Socialtjänstlagen kan ändå ses som ett försök att se sambanden mellan sociala problem och strukturella förhållanden - åtminstone på retorisk nivå. Lagstiftningens uppbyggnad och regelverk hade dock djupa rötter i tidigare barnavårds- och fattigvårdslagar och innebar inget principiellt avsteg från det rådande individualiserande synsättet.

\section{Några viktiga studier}

Det kan ses som en smula märkligt att man i lagstiftningssammanhang på 1950och 1960-talen inte kan se några spår av medvetenhet om relationen mellan sociala faktorer och barnavårdsproblem. Under 1940-talet producerades (i flera fall inom ramen för offentliga utredningar) nämligen ett antal omfattande studier av barnavår- 
dens klienter, alla med utgångspunkt från barnen men med mycket data om deras föräldrar. Dessa texter kan ses som en del i efterkrigstidens välfärdsprojekt där underpriviligerade och "problematiska" grupper, i samverkan mellan vetenskap och utredningsapparat, skulle identifieras och kartläggas. År 1944 kom Ungdomsvårdskommitténs betänkande om psykisk barna- och ungdomsvård (SOU 1944: 30). I en lång bilaga presenterade läkaren Gustav Jonsson, senare författare till den banbrytande boken Det sociala arvet, en undersökning om barn som var aktuella hos barnavårdsnämnderna. År 1946 publicerades Edith Otterströms Delinquence and children from bad homes. A study of their prognoses from a social point of view. ${ }^{1}$

En bärande tanke i dessa 40-talsstudier var att brottslighet och psykiska problem ärvs från föräldrar till barn. Men det var knappast en ny tanke vid denna tid. Den första mer omfattande svenska undersökningen med ett sådant tema kom ut redan 1918. Då publicerade David Lund sin avhandling om orsaker till ungdomsasocialitet. Lunds undersökningsgrupp bestod av intagna vid ungdomsanstalter vid seklets början och han konstaterade bland annat att $2 / 3$ av dem kom från fattiga hem. Huruvida fattigdom direkt kunde orsaka vanart lämnade Lund öppet, men att "det kan vara ett bidragande orsaksmoment i en del fall kan ej betvivlas» (Lund, 1923, se även Lund, 1918).

1 Till dessa studier skulle kunna läggas Sveriges första professor i barnpsykiatri, Sven Ahnsjös (1941), doktorsavhandling Delinquency in girls and its prognosis. Ahnsjö lägger emellertid mycket liten vikt vid barnens sociala position.
Edith Otterströms doktorsavhandling knappt 30 år senare hade ett tydligare socialt perspektiv, och redan titeln (se ovan) riktar intresset mot vilka hemförhållanden problematiska barn och unga kom från. Hon undersökte barnavårdsakter för drygt 2.000 barn och ungdomar (dubbelt så många pojkar som flickor) som aktualiserats vid barnavårdsnämnden i Malmö under närmare 40 år, i syfte att prognostisera deras utveckling. Föräldrarnas sociala position har ett särskilt kapitel och deras klassposition analyserades relativt noggrant. Otterström jämförde fäderna till barnen i undersökningen med en normalpopulation och konstaterade bland annat att 85 procent av barnavårdsungdomarna tillhörde arbetarklassen. För normalbefolkningen var siffran 62 procent (Otterström, 1946, s. 154). Man kan ifrågasätta mycket i Otterströms resonemang, som inte står fritt från vare sig den tidens moralism eller rasbiologiska diskussion (se även Ahnsjö, 1941). Undersökningen är dock med sin breda ansats och stora datamängd unik, inte bara i ett historiskt perspektiv.

Intressant på flera sätt är Gustav Jonssons 1940-talsundersökning av 4.400 barn och unga som på grund av egna beteendeproblem aktualiserats vid landets barnavårdsnämnder (SOU 1944:30). Också i detta fall är det imponerande att undersökningen överhuvudtaget kunde genomföras. I våra dagar finns ingen motsvarighet till en totalundersökning på barnavårdsområdet som baseras på ett så omfattande enkätmaterial. Jonsson försöker få grepp om de sociala faktorernas betydelse genom att till barnavårdsnämnderna ställa frågor om föräldrarnas yrke och eventuella fattigvårds- 
beroende. Han konstaterar bland annat: wmer eller mindre utpräglad fattigdom skulle sålunda enligt uppgiftslämnarnas åsikt föreligga i närmare $1 / 3$ av fallen" och att minst en fjärdedel av familjerna har fått fattigvård under undersökningsperioden (SOU 1944:30, s. 213-214). Jonsson konstaterar således att "fattigdom i hemmet och vanart bland barnen höra tydligen ofta ihop«, men också "att man inte får föreställa sig sambandet mellan fattigdom och asocialitet som alltför enkelt och direkt" (SOU 1944:30, s. 214).

Även under efterkrigstiden gjordes ett antal systematiska undersökningar av barnavårdens klienter om än utan jämförelser med normalpopulationer. I samband med de utredningar som gjordes inför 1960 års barnavårdslag presenterades en undersökning av bakgrundsförhållanden för de barn som placerades på institution (SOU: 1956: 61). ${ }^{2}$ Här framstår det tydligt hur föräldrars fattigdom kunde innebära att barnavården intervenerade. Vid mitten av 1950-talet var vanliga skäl till att barn institutionsplacerades föräldrars sjukdom/moderns barnsbörd, bostadsbrist eller bristande barntillsyn, alltså i princip faktorer som hade att göra med materiella brister (SOU: 1956:61, s. 802). När en liknande undersökning gjordes tjugo år senare (SOU 1974:7, s. 229-230) uppgavs sjukdom hos föräldrarna och bostadsproblem i betydligt färre fall än tidigare, men fortfarande utgjorde dessa mer eller mindra materiella omständighe-

2 Också tjugo år tidigare publicerades en omfattande undersökning om barn i institutionsvård (SOU 1942:45). Som en särskilt sårbar kategori beskrivs de som både är fattiga och barn till en ensamstående föräldrar(mor). ter skäl för omhändertagande i omkring en tredjedel av fallen.

Också Fosterbarnsutredningen (SOU 1974:7) pekade på fattigdom i skepnad av dåliga bostadsförhållanden bland omhändertagna barn. ${ }^{3}$ Man konstaterar att cirka två tredjedelar av barnen vid tidpunkten för omhändertagandet var trångbodda, och att en större del än befolkningen i övrigt bodde i lägenheter som saknade dusch, bad eller varmvatten (SOU 1974:7, s. 142-144, 297).

Barn placeras idag mycket sällan utanför hemmet med hänvisning till föräldrarnas trångboddhet eller fattigdom. Däremot har ett antal forskare sedan 1980-talet visat att föräldrar som tillhör arbetarklassen eller som aldrig kommit in på arbetsmarknaden, liksom familjer som är beroende av socialbidrag (olika mått har använts i olika studier) är klart överrepresenterade bland de som finns i barnavårdssystemet. I dessa nutida studier har denna överreprepresentation inte bara (som flera gånger tidigare) belagts utan även diskuterats ur ett klientperspektiv och lyfts fram som ett strukturellt problem (Hollander, 1985; Hessle, 1988; Andersson, 1995; Vinnerljung, 1996 a, b; Hessle \& Vinnerljung, 1999; Lundström, 2000). På detta vis skiljer denna forskning sig från äldre studier, där data som visade på förhöjd problemförekomst hos vissa grupper framstår som något "naturligt", något som har att göra med dessa gruppers bristande moral, dåliga arvsanlag eller andra slag av tillkortakommanden.

Det uppenbara sambandet mellan klass

3 Barnen var omhändertagna åren 1954-1970, så resultaten hänför sig delvis till förhållanden som ligger relativt långt tillbaka i tiden. 
och barnavårdsåtgärder eller annorlunda uttryckt mellan fattigdom och omhändertagande av barn och unga har inte satt tydliga spår $\mathrm{i}$ den offentliga diskursen som den kan avläsas i lagstiftningen. De viktiga undersökningar som presenterades i offentliga utredningar tycks inte ha haft något synbart genomslag i de åtgärder som föreslagits på området. Trots klara belägg för sambanden mellan sociala förhållanden och barnavårdsproblematik har de förklaringsmodeller som lagstiftningen byggt på utgått från individualiserade synsätt och problemen beskrivits som moraliska eller psykologiska/psykiatriska avvikelser. Man kan dock se klara skillnader i det sätt på vilket arbetarklassen eller de fattiga identifierats och uppfattats. I de utredningar som skrevs i slutet av 1800- och början av 1900-talet dominerar en tankefigur där arbetarklassen sågs som problematisk på grund av moraliska brister. Gradvis förlorade detta öppet moraliserande synsätt mark i den offentliga diskussionen. Med 1940-talets undersökningar märktes ett annat perspektiv, man började använda ett tänkande där man identifierade särskilt utsatta grupper. Med ett synsätt som har att göra med den framväxande välfärdsstaten började begrepp som överrepresentation och underprivilegierade grupper sakta göra sig gällande. Men det dröjer till 1970- och 1980-talen innan det faktum att vissa grupper är överrepresenterade i barnavården framstod som en social orättvisa i sig.

\section{Ligapojkar, sexualflickor och ensamma mammor}

I artikelns inledning pekade vi på att CSA vid seklets början uppmärksammade könets betydelse i den sociala barnavården. Detta dels som skillnader mellan fäders och mödrars egenskaper som fostrare (den oansvarige fadern och den vårdande modern) och dels som könsrelaterade skillnader i de faror som hotar det uppväxande släktet: flickor riskerade att hamna i osedlighet och prostitution, pojkar i brottslighet. Vi kan här se uttryck för tidens sätt att klistra vissa moraliska kategorier på specifika grupper och/ eller visst kön. Detta avsnitt skall uppmärksamma hur könsdimensionen framträder i definitionsprocessen kring sociala problem och i samhällets interventioner.

Vi skall börja med att diskutera könsskillnader bland de ungdomar som blir föremål för åtgärder på grund av att deras beteende ifrågasätts. Det handlar alltså främst om tonåringar inte om små barn. För yngre barn är det svårt att se betydelsen av kön vid omhändertagande, eftersom ingripandena motiveras av föräldrars svårigheter eller brister. När det gäller omhändertaganden av ungdomar har Gustav Jonsson uttryckt sig drastiskt: „Uttryckt på ren och oförfalskad svenska: Ska vi klämma åt pojkarna, då tar vi dom som tjuvar, men ska vi ta i ordentligt mot flickorna, då tar vi dom som småfnask!» (Jonsson, 1977, s. 39). Citatet kommer från Jonssons Flickor på glid - en studie i kvinnoförtryck som kom ut i slutet på 1970-talet (med uppföljaren Flickor på glid - en studie $i$ kvinnoförakt, Jonsson, 1980). Vad Jonsson uttrycker är ett tydligt historiskt tema i barnavården nämligen ett könsmässigt delat norm- och åtgärdssystem för ungdomar. Man har från myndigheternas sida - och i samhället i stort - bedömt ungas beteende utifrån kön, vilket också inneburit att de 
barnavårdande åtgärderna sett olika ut för flickor och pojkar.

Lite tillspetsat kan man tala om ett flickåtgärdssystem och ett pojkåtgärdssystem. För flickor har sexualitet haft en särställning och getts en innebörd som motiverat omhändertagande för att de är "lössläppta», promiskuösa, sexuellt vanartade osv. Jonsson skrev om de "s.k. sexualflickorna" (Jonsson, 1977 s. 39) och karaktäriserade den typiska Skåflickan i följande punkter: "tuff tonårstjej, ligger med pojkar och unga män till höger och vänster, struntar i skolan, rymmer och stjäl, drar sig inte för att slå till om det behövs» (Jonsson, 1977, s. 40-41). Skåflickorna visade i stort liknande avvikelser som pojkarna, men det stora undantaget är flickornas sexualitet som problematiseras i så hög grad. För pojkarna har i stället stöldbrotten en särställning som könsskiljande huvudproblem.

Ingripanden mot flickor som motiveras av deras "sexuella vanart" har en lång historia. För att återknyta till Gustav Jonssons undersökning om barnavårdsklientelet i början av 1940-talet så förekom sexuell vanart ensamt eller i kombination med annat i 2/3 av fallen bland de flickor som aktualiserades för åtgärder (SOU 1944:30, s. 254). Även i Otterströms (1946) undersökning återfinns höga siffror för sexuell vanart, särskilt bland de äldre flickorna och de som bedömdes uppvisa allvarligare former av vanart. Kersti Ericsson (1997, s. 33) som forskat om den norska barnavården talar, med en parafras på Tove Stang Dahls (1978) norska klassiker Barnevern og samfunnsvern, om barnavården som ett "sexuellt samfunnsvern" där flickors sexualitet bestraffas och problematiseras.
Man kan hitta tidiga tydliga exempel på att också synen på insatsernas utformning kopplats till kön och könsrelaterade problembeskrivningar. I den tidiga barnavården, runt förra sekelskiftet, fanns en idé om att underklassflickor som kom i barnavårdens händer skulle tränas till att bli dugliga tjänarinnor. Det fanns fler barnhem för flickor än för pojkar (fast totalt sett placerades fler pojkar än flickor på institution) och ett viktigt inslag på flickbarnhemmen var att lära de fattiga flickorna enklare hushållsgöromål och rusta dem till att bli pigor och barnjungfrur i de fina familjerna. Barnhemmen skulle ha hemmet som förebild och flickorna fick genom sitt arbete bidra till »det gemensamma hushållet». Pojkarna var inte lika intressanta som hushållsarbetskraft och skulle istället rustas till att bli arbetskraft på »den vanliga» arbetsmarknaden (Söderlind, 1999; se även Fattigvårdslagstiftningskommitténs betänkande IV. Barnavårdslagstiftningen, 1921, s. 249)

I början av 1940-talet var det mycket större risk för flickor som var aktuella hos barnavårdsnämnden att hamna på anstalt än för pojkar. Särskilt stor var överrepresentationen bland flickor som bedömdes som sexuellt vanartade i kombination med något annat beteendeproblem (SOU 1944:30, s. 254). Det faktum att flickor löpte större risk att hamna på anstalt måste ses mot bakgrund av att det var tre gånger så vanligt att pojkar överhuvudtaget aktualiserades för åtgärder hos barnavårdsnämnden. I absoluta tal dominerade pojkarna även inom anstaltsvården. Den vanligast "pojkåtgärden« var dock varning (som utgjorde en del av det formella åtgärdssystemet). Det förefaller 
med andra ord som om för de flesta pojkar som var aktuella för något småbrott nöjde sig barnavårdsnämnden med en åthutning, medan man för de, i absoluta tal färre, flickor som kom in i systemet såg betydligt allvarligare på problemen, särskilt om de på något sätt hade att göra med sexualitet (SOU 1944:30, s. 254). Skuldbeläggningen av flickor pekar mot något som är särskilt problematiskt med sexuell vanart (för att nu använda det tidstypiska begreppet) som socialt problem. Ett exempel är Edith Otterström (1946) som använder begreppet sexuell vanart (sexual delinquency) också om de utsatta flickor där det av hennes fallbeskrivningar framgår att de utnyttjats av äldre män.

Hans Swärd (1993) har undersökt barnavårdsnämndens i Malmö ingripanden mot ungdomar under första halvan av 1900talet. Titlarna på delarna i hans bok ger en bild av förhållandet mellan problembilder och kön. Den första delen heter ligapojkarna och den tredje raggarflickorna. Swärd visar hur de problembilder som etablerats i den offentliga diskursen på olika sätt påverkat barnavårdsnämndens agerande. Det gäller exempelvis 1930-talets debatt om den moraliska upplösning som sades följa på det så kallade dansbaneeländet och 1950- och 1960-talets moraliska panik kring raggarna och "raggarbrudarnas» agerande inte minst i sexuellt avseende.

Man kan säga att den sexuella vanarten försvann ur i vart fall den officiella barnavårdsdiskussionen (om än inte från dess praktik) i samband med att raggarfrågan utmönstrades ur debatten i slutet av 1960talet. Sunesson (2002) har visat att bland ungdomsvårdskoleflickor kulminerade sex- uell vanart som ingripandegrund i början av 1960-talet. Detta för att sedan nästan helt försvinna när knarket tog över som central social problematik bland ungdomar. Då försvann också flickorna ur synfältet för lång tid. Särskilt tydligt blir detta i texterna kring lagstiftningen, där könsskillnader eller "flickproblem» inte uppmärksammas.

Det senaste mer omskrivna arbete som grundligt fokuserade på flickor är Gustav Jonssons tidigare omnämnda böcker från 1970- och 1980-talen om "flickor på glid«. Med detta undantag är det under flera decennier påfallande tyst om dem, men i Anderssons (1990, 1993, 1996) arbeten riktas dock uppmärksamheten mot utsatta flickor med missbruksproblem. Här visas att för flickor tolereras från myndigheternas sida mycket mindre av asocialt beteende än för pojkar. När asocialitet ( $\mathrm{t}$ ex kriminalitet och missbruk) förekommer betraktas det som mer allvarligt, i synnerhet om det finns en koppling till flickors sexuella beteende. Även Schlytter (1999) diskuterar skillnader $\mathrm{i}$ hur socialvården och rättssystemet relaterar till flickor respektive pojkar vid omhändertaganden. Hon pekar på att flickors sexualitet tillmäts speciell betydelse i praktiskt socialt arbete, men knappast alls får någon plats i den diskurs som omger barnavården. Det finns olika normer för pojkar och flickor, vilka innebär att pojkar kan vara besvärligare för omgivningen innan barnavården griper in. Den vikt som läggs vid åtgärder som har att göra med "pojkrelaterade" problem i den offentliga diskussionen märks inte minst i de offentliga utredningar som lett fram till »hårdare tag« mot ungdomskriminalitet (SOU 1992: 18; SOU 1993:35). 
Om man går till statistiken finner man fram till socialtjänstreformen i början av 1980-talet en långvarig övervikt för pojkar när det gäller mindre ingripande åtgärder som övervakning, men också när det gäller vård utanför hemmet. Det senare gäller främst de äldre pojkarna. Särskilt stor är överrepresentationen när det gäller tvångsvård på grund av eget beteende (Samhällets barnavård 1931, 1937, 1944, 1946, 1952, 1957, 1967, Socialvården, 1972, 1977, 1982). I dagens åtgärdssystem finns endast svaga könsskillnader när det gäller placering utanför hemmet. Pojkarnas överrepresentation begränsar sig till åldern 15-21 år, men där är den å andra sidan stor. Det gäller särskilt vid placering på de så kallade $§ 12$-hemmen, med rötter i de gamla ungdomsvårdsskolorna. När det gäller förebyggande åtgärder finns en påtaglig övervikt av pojkar i alla åldrar i insatsen kontaktmannaskap, särskilt för tonåringar (Socialstyrelsen, 2002). Över tid kan man alltså säga att kön kommit att spela mindre roll för yngre barn när det gäller risken att bli omhändertagen, men för tonåringarna kvarstår en förhöjd risk för pojkar att komma in i barnavårdssystemet och de löper också större risk att hamna i en restriktiv vårdmiljö (vilket inte behöver motsäga att de jämförelsevis färre tonårsflickor som kommer in i systemet riskerar att behandlas hårdare).

Lundström \& Vinnerljung (2001) har visat att antalet omhändertaganden av unga över tolv år ökat kraftigt under 1990-talet. De menar att bland annat en hårdnande attityd mot ungdomsbrottslighet ligger bakom denna uppgång. Att också alltfler tonårsflickor omhändertas under 1990- talet är svårare att förklara. Om ökningen av tonårsplaceringar huvudsakligen har sin bakgrund i "pojkproblem" som kriminalitet och annat asocialt beteende, borde inte flickomhändertaganden öka. Möjligen kan man tänka sig att ökningen för flickornas del kan bero på relationsproblem i familjerna, rymningar och utstötningar. Att det är fler flickor än pojkar i samhällsvård som har en sådan problembakgrund framgår i Vinnerljung, Sallnäs \& Kyhle Westermark (2001). Men det mest slående är ändå hur lite systematisk kunskap det finns om skälen till att barn och ungdomar blir omhändertagna och vilka könsrelaterade mönster som finns. Detta blir särskilt tydligt om man försöker förstå förändringar när det gäller flickorna. Är det så att de i högre grad uppvisar mönster som tidigare sågs som typiskt för pojkar och/eller kan ökningen kopplas till ett historiskt förankrat könsmässigt åtskilt normsystem som innebär att flickor fortfarande omhändertas för handlingar som har att göra med deras sexualitet?

\section{Ensamma mammor}

Om man idag finner en viss överrepresentation för pojkar bland de äldsta tonåringarna, men i övrigt inga större könsskillnader bland barnen är bilden en annan för deras föräldrar. Här finns mycket klara könsskillnader. Karen Swift (1995) har i boken Manufacturing Bad Mothers pekat på hur brister bland familjer som har kontakt med socialvården så tydligt knyts till moderskapet och kvinnan. I de kanadensiska barnavårdsutredningar hon gått igenom blir det tydligt att det är modern som skuldbelastas och att det är på henne som ansvaret läggs. 
Ensamstående mödrar har "alltid" betraktats som särskilt problematiska ur barnavårdssynpunkt. I texterna kring de första barnavårdslagarna finns en tydlig problemfokusering kring barn födda utanför äktenskapet och deras mödrar. År 1921 föreslog Fattigvårdskommittén att ensamma mödrar som behövde fattigvårdsunderstöd skulle överflyttas till barnavårdsnämnden. Att vara fattig och ensamstående förälder kopplades med andra ord direkt samman med barnavårdsproblem. Lagförslaget gick dock inte igenom, bland annat med argumentet att man riskerade orättvisor genom att ensamma mödrar skulle få mer stöd än andra fattiga familjer (Proposition 1924:150). Ett annat uttryck för problematiseringen av den ensamma modern är det obligatoriska barnavårdsmannaskapet som infördes 1917. Alla barn födda utanför äktenskapet ansågs behöva speciell tillsyn från samhällets sida, oavsett hur deras faktiska situation såg ut. Barnavårdsmannen skulle hjälpa till att fastställa faderskap, kräva in underhåll, men också ge modern råd och stöd i sin föräldraroll. Obligatorisk barnavårdsman avskaffades inte förrän 1974.

Gustav Jonsson diskuterade de så kallade u.ä. barnen (det vill säga i praktiken framförallt barn till ensamma mammor) i starkt problematiserande termer i sin utredning om barnavården från mitten av 1940-talet. Han konstaterar att u.ä. barn är kraftigt överrepresenterade i barnavårdspopulationen och att orsakerna kan vara att de vuxit upp under sämre materiella, sociala och psykologiska livsvillkor, men också att deras föräldrar kan vara "något sämre utrustade som anlagsbärare» (SOU 1944:30, s. 208). Jonsson menar att barns utomäktenskapliga börd i sig skall ses som »en signal« om att de behöver särskilt stöd (SOU 1944:30, s. 211).

Barn till ensamstående mödrar är också en grupp som historiskt har befolkat institutionsvården. Långt fram under 1900talet fanns särskilda så kallade mödrahem. Dessa var avsedda för ogifta mödrar som av ekonomiska eller andra skäl inte ansågs kunna ta hand om sina barn (Sallnäs, 2000). Med välfärdsstatens framväxt försvann denna speciella insats för de ensamma mödrarna. Ensamstående mödrars barn är dock fortfarande (och möjligen också i växande grad) kraftigt överrepresenterade i omhändertagandestatistiken. Det gäller både i institutionsvård och fosterbarnsvård och såväl yngre som äldre barn (Lundström, 2000). För barnhemsvården visar exempelvis Kanters (1998) undersökning av barn (0-12 år) på akutinstitutioner i Stockholms län att omkring 70 procent av de barn som skrevs in kom från hushåll med ensamma mödrar. Av de ungdomar som skrevs in på § 12-hem år 1998 kom endast cirka en fjärdedel från familjer med två föräldrar (SiS, 2001). Också när det gäller förebyggande åtgärder som kontaktfamilj är barn till ensamstående mammor överrepresenterade (Lundström, 2000).

Man kan tänka sig olika och sinsemellan kompletterande förklaringar till att ensamma mammor är överrepresenterade i barnavårdsstatistiken, och att de "alltid" varit det. Det kan handla om att de faktiskt har en svårare situation just genom att de är ensamma, men det kan också vara uttryck för att de uppmärksammats och problematiserats på ett särskilt sätt. Sannolikheter för att barnavården skall "få syn på dem» 
är stor eftersom de oftare än andra föräldrar behöver samhällelig ekonomisk hjälp. I dagens forskning tyder mycket på att det faktum att någon är »ensamförälder" i sig knappast kan förklara förekomst av psykosocial problematik hos barnen. Att vara ensamförälder kan inte ensamt ses som en problemalstrande faktor (Lagerberg \& Sundelin, 2000). Det finns således anledning att fråga sig om barnavårdens institutioner agerar utifrån en överproblematiserande syn på ensamstående föräldrar.

\section{Etnicitet, invandrarskap och överrepresentation}

Liksom klass är begreppen etnicitet och invandrare svårdefinierade och långt ifrån historiskt konstanta. Alexandra Åhlund (2002) menar att "invandrare« konstrueras som en social kategori genom att det finns bestämda föreställningar om vad som är svenskt vilket likställs med att vara normal. Från denna utgångspunkt utvecklas bilden av "de andra" som främmande och som icke-svenskar (Åhlund, 2002, s. 294). Vissa (etniska) grupper påförs egenskaper som uppfattas som osvenska, $t$ ex att vara traditionstyngd eller omodern. Vi använder i artikeln begreppen invandrarskap och etnicitet som samlingsbegrepp för grupper i samhället som av andra ( $\mathrm{t}$ ex lagstiftare eller statistikförare) definieras som ickesvenskar, d.v.s. som i någon mening kulturellt främmande.

I internationell litteratur visas hur barnavården $\mathrm{i}$ vissa sammanhang varit ett direkt led i förtryck och diskriminering av etniska minoriteter. Karen Swift (1995) talar i sin kritiska genomgång av hur barna- vårdsproblem konstrueras om "the colour of neglect«. När det gäller den svenska sociala barnavårdens förhållande till etniska minoriteter kan man slå fast att grundliga undersökningar helt saknas. Detta till skillnad från andra länder där det finns många exempel på forskning om hur etniska minoriteter behandlats av sociala myndigheter. Det gäller särskilt aboriginals i Australien och indianer i USA och Canada. Man har kunnat visa att barnavården utgjort en del av ett systematiskt förtryck av minoritetsgrupperna, framförallt genom mer eller mindre tvångsmässiga systematiserade omhändertaganden och adoptioner (Bagley, 1991; Swift, 1995; Human Rights and Equal Opportunity Commission, 1997). Någon motsvarande forskning finns inte i Sverige.

För Sveriges del har barnavården varit tätt kopplad till läkarna och medicinen. Under första halvan av 1900-talet dominerande läkarna i barnavårdsdiskursen och var något av frontfigurer i det "projekt" som på 1930- och 1940-talen gick ut på att människor med dåliga anlag skulle berövas sin reproduktiva förmåga. Det handlade inte bara om etnicitet utan om att personer som ansågs vara utvecklingsstörda eller begåvningshandikappade steriliserades (med eller mot sin vilja). Också individer som inte alls hade en begåvningsnedsättning kunde drabbas, kanske pga. av ett rent fysiskt handikapp. Steriliseringarna utgjorde en del av ett rashygieniskt/rasbiologiskt tänkande som spelade en stor roll i samhället främst på 1930- och 1940-talen (Runcis, 1998).

Även om det är ont om källmaterial finns det skäl att anta att den sociala barnavården utgjorde en del i det rashygieniska projektet. Det finns åtminstone spår av detta i de 
programmatiska skrivningarna. Främst var det tattare och zigenare som pekades ut. I tidiga utredningstexter, från 1920-talet, beskrivs de som samhälliga plågor (se översikt om "tattarproblemet" i Svensson, 1993, se också Bergstrand, 1942). När det gäller tattarna fanns förslag som gick ut på att tidigt ingripa mot barnen och placera dem $\mathrm{i}$ samhällsvård. I en lokal undersökning gjord på uppdrag av barnavårdsnämnden i Jönköping inventerades antalet tattare och utredaren Tor Jacobsson (som gjort utredningar också för CSA) föreslog åtgärder som generell tvångssterilisering och placering av alla tattarbarn i särskilda anstalter (Jacobsson, 1944). Parallellt med att tattarna som grupp problematiserades starkt som föräldrar, fördes resonemang om yttre orsaker till tattarnas ofta svåra livssituation. ${ }^{4}$

Rent faktiskt är det svårt att få ett grepp om antalet omhändertagande av barn till de som av statsmakterna definierades som tattare. I en Socialstyrelseskrift från mitten av 1940-talet angav man att omkring hundra av ca 3.500 barn var omhändertagna. Det motsvarar mellan tre och fyra procent, vilket får sägas vara en närmast låg andel (Socialstyrelsen, 1945, s. 386, 389-340). Siffran får dock ses som en mycket grov uppskattning. I Jönköpingsundersökningen var drygt 20 procent av tattarnas minderåriga barn någon gång under undersöknings-

4 Vid ungefär samma tid gör Socialstyrelsen en räkning av de tattare och zigenare som finns i riket (Socialstyrelsen, 1945). Den är föranledd av klagomål om att tattarnas levnadssätt inneburit problem för den övriga befolkningen på en del orter, men det anges inget specifikt skäl till att också räkna hur många zigenarna som finns i landet. året omhändertagna, alltså betydligt högre siffror än vad som redovisas av Socialstyrelsen. Dock var inga barn från Jönköping omhändertagna enligt barnavårdslagens tvångsparagrafer (Jacobsson, 1944, s. 84).

I ett historiskt perspektiv finns det utöver det vi nämnt ovan få fakta om den sociala barnavårdens ingripanden mot etniska minoriteter. I de texter vi diskuterat nämns ibland tattare och zigenare som problematiska grupper vars barn omhändertagits (se exempelvis Otterström, 1946), men det finns inga markeringar av etnicitet eller invandrarskap i den offentliga statistiken. ${ }^{5}$

\section{"Invandrarna"}

De moderna diskussionerna om invandring har sina rötter i 1970- och 1980-talet då Sverige i större skala börjat ta emot invandrare och det började finnas grupper av barn och unga med ursprung utanför Sverige och de nordiska länderna. Också de "gamla" grupperna med kulturell särart diskuterades, men tonar nu fram från ett annat perspektiv i socialarbetardiskursen. Tattare nämns inte. Begreppet är så att säga utmönstrat ur den officiella vokabulären, men inte heller uttryck som resande gör sig gällande. Zigenarna/romerna däremot uppmärksammades, men nu som föremål för enbart "godau avsikter, i det här fallet speciella familjepedagogiska och sociala insatser (se Takmans, 1976 undersök-

5 Se dock SOU 1956:61 där man i en undersökning av fosterbarnen år 1954 konstaterade att sex procent är utländska medborgar. Det framstår som en stor andel, men man får inte någon förklaring till detta i utredningen. 
ning om zigenarnas levnadsförhållanden). Romerna utnämndes till målgrupp för ett socialt arbete som skulle hjälpa en marginaliserad grupp att bevara sin hotade kultur parallellt med försök att förbättra deras försörjningssituation (Socialstyrelsen, 1978, 1991).

Om vi nu lämnar romer och tattare, när blir etnicitet och invandrarfrågor mera generellt en fråga i de offentliga texterna och hur går resonemangen? I Fosterbarnsutredningens betänkande från 1974 (SOU 1974:7) behandlades etnicitet endast mycket kortfattat. Man konstaterade att ett av tio fosterbarn har utländsk nationalitet och att många av dem är adoptivbarn som placeras i avvaktan på adoption. Vi kan alltså konstatera att vid denna tid är etnicitet ännu ingen fråga i barnavården och det finns ingen koppling mellan "invandrare" och överrepresentation i fosterbarnsvården.

I en rapport från Delegationen för social forskning från 1986 med namnet Omhändertagande av invandrarbarn i Sverige. Var står forskningen idag?, uppmärksammades frågan utifrån rapporter om finska barns överrepresentation i omhändertagandestatistiken. Frågan om var forskningen står besvaras något hårddraget med att man vet ingenting alls. Det är emellertid just från 1980-talet som invandrarskap etableras som en problematisk kategori i barnavårdsdiskursen. Framförallt handlar det om ungdomar (och då pojkar) och deras överrepresentation i kriminalstatistiken och på landets ungdomsinstitutioner (Bergström \& Sarnecki, 1993; Sarnecki, 1996). "Invandrarfrågan" uppmärksammas också i offentligt tryck, till exempel i Socialstyrel- sens $(1995,1998)$ skrifter om socialt arbete med barn från etniska minoriteter.

I slutet av år 2000 är invandrare och etniska minoriteter helt etablerade "problematiska" kategorier i texter om barnavård. Det är ett välkänt faktum att barn med invandrarbakgrund är överrepresenterade i barnavårdssystemet och inte minst $\mathrm{i}$ vård utanför hemmet. På de särskilda ungdomshemmen - institutioner för de mest problembelastade tonåringarna - finns en särskilt stor överrepresentation av invandrarpojkar. I en rapport från det så kallade Välfärdsbokslutet konstateras att risken att placeras i dygnsvård är mer än dubbelt så stor för invandrarbarn (bägge föräldrarna födda utomlands) under 12 år jämfört med svenska barn. För tonåringar är risken tre gånger så stor. Det har inte skett någon ökning av invandrarnas andel under 1990talet, men överrisken för omhändertagande är konstant hög bland familjer där föräldrarna är födda utanför Sverige (Lundström \& Vinnerljung, 2001).

Det behöver sägas att begreppet invandrare ofta är grovt definierat och inkluderar människor som sinsemellan är mycket olika. Deras gemensamma nämnare är att de $\mathrm{i}$ ett kontrastivt perspektiv betraktas som "icke-svenskar». Den överrisk vi talar om är långt större än vad välfärdsbokslutets siffror visar för vissa »icke-svenska" grupper, medan den är icke-existerande eller försumbar för andra.

En viktig insikt från kriminologisk forskning är att invandrarungdomars överrepresentation i brottsstatistiken har att göra med att deras familjer oftare har lägre inkomster, sämre anknytning på arbetsmarknaden och bor i mer belastade 
bostadsområden. Skrapar man på ytan visar det sig att överrepresentationen snarare handlar om klass än etnicitet (se Estrada, 1999). På samma sätt förhåller det sig sannolikt också inom barnavården. Klass och etnicitet hör med andra ord ihop i ett komplicerat mönster. Precis som när det gäller de ensamma föräldrarna finns det anledning att fråga sig vilket perspektiv den sociala barnavården representerar i dessa frågar. Har den sociala barnavården bidragit till att klass döljs när barnavårdsfrågan betraktas utifrån en etnisk dimension?

\section{Avslutning}

Forskare från engelskspråkiga länder brukar använda begreppen class, gender och ethnicity som markörer för den sociala utsatthet som utmärker familjer vilka blir föremål för åtgärder från den sociala barnavårdens sida (Egelund, 1997; Frost \& Stein, 1989; Parton, Thorpe \& Wattam, 1997; Swift, 1995). Som framkommit i denna text kan samma sak sägas om svenska förhållanden. Familjers fattigdom i olika skepnad, att vara kvinna och ensamstående förälder, att ha så kallad invandrarbakgrund eller att tillhöra en kulturell/etnisk minoritet är faktorer som ökar risken för samhällsingripanden när det gäller barnen (Andersson, 1995; Hessle, 1988; Hollander, 1985; Lundström, Vinnerljung, 1996a, b).

Sett i ett hundraårigt perspektiv - det vill säga så länge som vi haft en sammanhållen barnavårdslagstiftning - kan man tala om tre olika sätt att identifiera problematiska grupper i den officiella diskursen. Det första handlar om utpekande av moraliskt bekymmersamma kategorier (sexualflickor, ligapojkar, besvärliga tattare eller en degenererad arbetarklass). Det andra handlar om psykologiska/psykiatriska kategoriseringar (psykopati, relationsproblem, DAMP etc.). Det tredje rör sig om identifiering av "objektivt» bestämda kategorier som ofta identifieras via faktisk eller antagen överrepresentation (socialgrupper, ensamma kvinnor eller invandrare) inom barnavårdspopulationen. I efterhand kan man påföra egenskaper som gör gruppernas eventuella överskott av sociala problem begriplig.

I en analys av den offentliga diskursen kan vi se att klass och kön har varit och fortfarande är centrala frågor i den offentliga barnavårdsdiskursen. Etnicitet är en fråga som fått en central plats på dagordningen först i slutet av 1900-talet i samband med att Sverige blivit ett mångkulturellt samhälle.

I början av 1900-talet diskuterades klass- och könsfrågor främst i moraliska termer, medan psykiatriska/psykologiska förklaringsmodeller dominerat förståelsen av sociala problem inom barnavården under resten av 1900-talet. Sambandet mellan moraliskt och normativt tänkande och barnavård är tydligt i officiella texter från seklets början, där moraliska egenskaper tydligt kopplades till klass och kön. Men också idag kan vi observera att förskjutningar i de normativa systemen kan få direkt utslag i barnavården. Den kraftiga ökningen av antalet omhändertagna tonåringar under 1990-talet kan sannolikt till en del förklaras av en förändrad syn på hur brottslighet bland unga skall hanteras (Lundström \& Vinnerljung, 2001). Också de individualpsykologiska kategoriseringarna har en stark ställning i diskurs och praktik och hör ihop med vissa yrkesgrup- 
per, t ex psykologer och läkare. Med framväxten av dessa professioner följde ett individualiserat problemperspektiv som idag är starkt cementerat.

Särskilt från 1940-talet och framåt märks ett antal forskningsrapporter och offentliga utredningar där överrepresentation av grupper som "u.ä. barn" (det vill säga barn till ensamma mammor), barn till fattiga föräldrar och pojkar inom barnavårdspopulationen på olika sätt uppmärksammas. Överrepresentationen sågs emellertid inte som ett rättviseproblem eller som ett uttryck för strukturellt förtryck. Snarare blir överrepresentationen i den rådande tidsandan naturlig eftersom man kunde förvänta sig att individer med icke önskvärda individuella egenskaper i större utsträckning än andra blir fattiga, frånskilda etc. Här skall dock noteras att somliga forskare noterar den "eviga frågan«: Är det fattigdom som leder till individuella problem eller är det människor med individuella problem som i högre grad än andra hamnar i fattigdom (se Lundström \& Wiklund, 2000 för en diskussion).

Att överrepresentation av specifika grupper betraktas som ett uttryck för strukturell orättvisa eller förtryck märks först i socialtutredningen från mitten av 1970-talet (men då bara glimtvis) samt i ett antal forskningsrapporter från 1980-talet. Under de senaste 15 åren kan man bland forskare också finna flera exempel på kritiska diskussioner om hur barnavården som organisation agerar för att identifiera sociala problem. Man har pekat på att grupper som på grund av ekonomiska bekymmer har kontakt med socialvården löper större risk än andra att få sina barn omhändertagna samt att barnavården är känslig för såväl förändringar i omgivningen som ökade krav på omhändertaganden från domstolarnas sida. Detta till trots kan man dock fortfarande tala om vad man skulle kunna kalla en strukturell blindhet i de centrala offentliga texterna om social barnavård.

Vi har kunnat konstatera att den sociala barnavården aldrig blivit en del av den generella socialpolitiken. Barnavården har inte som förskolan och andra moderna institutioner lyckats spränga fattigvårdsskalet, för att använda Sune Sunessons (1990) uttryck. Trots att man sedan lång tid tillbaka kunnat konstatera att barnavårdsproblem inte fördelas slumpmässigt i befolkningen, utan att deras spridning hänger ihop med strukturella förhållanden har inte det i någon grundläggande mening förändrat barnavårdens karaktär. Grundbulten $\mathrm{i}$ arbetet består fortfarande av individuella ingripanden. Socialtjänstens barnavård är oförändrat en inrättning som betraktas med misstänksamhet och som tenderar att stigmatisera sina klienter.

På basis av den forskningsbaserade kunskap vi har och den kunskap som finns "på fältet" borde det ändå gå att diskutera lokala och nationella socialpolitiska insatser utifrån den sociala barnavårdens klientarbete och de behov som identifieras via detta. Med en sådan socialpolitisk utgångspunkt borde barnavårdsproblem, mätt i antal omhändertaganden, antal förebyggande åtgärder o.s.v., tillsammans med andra faktorer kunna användas som välfärdsindikatorer när man utformar socialpolitiska reformer lokalt och nationellt. Eftersom social barnavård (liksom missbruksproblem) i så stor utsträckning 
har betraktats som individuella eller moraliska avvikelser har de hamnat utanför den socialpolitiska diskursen. Det borde också vara möjligt att $i$ de individuella fallen i större utsträckning ta fasta på faktorer som har med strukturell underordning att göra. Med andra ord: På vilket sätt kan den sociala barnavården fungera kompenserande för de enskilda individerna? Kunskaperna om vad som faktiskt görs i den sociala barnavården är små, men det är ändå viktigt att fråga i vilken utsträckning man för individerna lyckas kompensera för socioekonomiskt relaterade resursbrister.

\section{Referenser}

Ahnsjö, S. (1941) Delinquency in girls and its prognosis. Uppsala: State institute on human genetics and race biology.

Andersson, C. (1990) Dåliga flickor är inte det sämsta. En kunskapsöversikt om flickor i riskzon och missbruk. Stockholm: Stiftelsen kvinnoforum.

Andersson, C. (1993) The children of Maria: adolescent substance abusers, their families and schooling. Stockholm: Almqvist \& Wiksell International.

Andersson, C. (1996) Om struliga flickor: Beteende och bemötande. I Armelius, B.Å., Bengtzon, S., Rydelius, P.A., Sarnecki, J. \& Carpelan, K.S. (red.) Vard av ungdomar med sociala problem: En forskningsöversikt. Stockholm: Statens institutionsstyrelse.

Andersson, G. (1995) Barn i samhällsvård. Lund: Studentlitteratur.

Bagley, C. (1991) Adoption of native children in Canada: a policy analysis and a resarch report. I Altstein, H. \& Simon, R. (red.) Intercounty adoption: A multinational perspective. New York: Praeger.

Bergstrand, C-M (1942) Tattarplågan. Göteborg: Gumperts förlag.

Bergström, U. \& Sarnecki, J. (1996) Invandrarungdomar på särskilda ungdomshem i Stockholm län. I Armelius, B.Å., Bengtzon, S., Rydelius, P.A., Sarnecki, J. \& Carpelan, K.S. (red.) Vård av ungdomar med sociala problem: En forskningsöversikt. Stockholm: Statens institutionsstyrelse.
Betänkande och förslag angående minderåriga förbrytares behandling, 1898.

Betänkande och förslag angående vanartade och i sedligt avseende försummade barns behandling, 1899.

CSA (1906) Berättelse öfver förhandlingarna vid Kongressen för Fattigvård och Folkförsäkring $i$ Stockholm, 1906. Stockholm: CSA.

Dahl, T. Stang (1978) Barnevern og samfunnsvern. Oslo: Pax forlag.

Delegationen för social forskning (1986) Omhändertagande av invandrarbarn i Sverige. Var står forskningen idag? Stockholm: DSF.

Egelund, T. (1997) Beskyttelse af barndommen: socialforvaltningers risikovurdering og indgreb. København: Reitzel.

Ericsson, K. (1997) Drift og dyd. Kontrollen av jenter på femtitallet. Oslo: Pax forlag.

Estrada, F. (1999) Ungdomsbrottslighet som samhällsproblem: Utveckling, uppmärksamhet och reaktion. Stockholm: Kriminologiska institutionen, Stockholms universitet.

Fattigvårdslagstiftningskommitténs betänkande IV (1921). Barnavårdslagstiftningen.

Frost, N. \& Stein, M. (1989) The politics of child welfare: inequality, power and change. New York: Harvester Wheatsheaf.

Hessle, S. (1988) Familjer $i$ sönderfall: en rapport från samhällsvården. Stockholm: Norstedt.

Hessle S. \& Vinnerljung, B. (1999) Child welfare in Sweden: An overview. Stockholm: Departement of social work, Stockholm university.

Hollander, A. (1985) Omhändertagande av barn: 
en studie av barnavårdsmål vid förvaltningsdomstolarna åren 1974, 1977 och 1982. Stockholm: Aktuell juridik.

Human Rights and Equal Opportunity Comission (1997) Bringing them home. National inquiry into the seperation of aboriginal and Torres Strait chidren from their families. Sydney: Human Rights and Equal Opportunity Commission.

Isberg, H. (1906) Fattigvården och det uppväxande släktet. I Berättelse över förhandlingarna vid Kongressen för Fattigvaird och Folkförsäkring $i$ Stockholm, 1906. Stockholm: CSA.

Jacobsson, T. (1944) Om tattare i Jönköping. Redogörelse för vissa, på uppdrag av Jönköpings stads fattigvårdsstyrelse företagna undersökningar. Jönköping: Fattigvårdsstyrelsen.

Jonsson, G. (1977) Flickor på glid: en studie i kvinnoförtryck. Stockholm: Tidens förlag.

Jonsson, G. (1980) Flickor på glid: en studie i kvinnoförakt. Stockholm: Tidens förlag.

Kanter, A. (1998) Barn på barnhem: ett projekt om barn på akut och utredningshem. Slutrapport. Stockholm: Stockholm HVB/Stockholms stad.

Lagerberg, D. \& Sundelin, C. (2000) Risk och prognos $i$ socialt arbete med barn: Forskningsmetoder och resultat. Stockholm: Gothia/CUS.

Lund, D. (1918) Über die ursachen der Jugendasozialität. Stockholm. Almqvist \& Wiksell.

Lund, D. (1923) Ungdomsbrottslighet och vanart $i$ Sverige, deras orsaker och bekämpande. Svenska sällskapets för rashygien skriftserie. Lund: Gleerups.

Lundström, T. (1993) Tvångsomhändertagande av barn: en studie av lagarna, professionerna och praktiken under 1900-talet. Stockholm: Stockholms universitet, Socialhögskolan.

Lundström, T. (2000) Om kommunernas sociala barnavård. I Szebehely, M. (red.) SOU 2000:38. Välfärd, vård och omsorg. Antologi från Kommittén välfärdsbokslut.

Lundström, T. \& Wiklund, S. (2000) Att växa up i familjer med långvarigt försörjningsstöd: En forskningsöversikt om barns uppväxtvillkor $i$ familjer emd socialbidrag och små ekonomiska resurser. FoU-rapport 2000:3. Stockholm:
Socialtjänstförvaltningen, FoU-byrån

Lundström, T. \& Vinnerljung, B. (2001) Omhändertagande av barn under 1990-talet. I Szebehely, M. (red.) SOU 2001:52. Välfärdstjänster $i$ omvandling. Antologi från Kommittén välfärdsbokslut.

Løkke, A. (1989) Vildfarende børn - om forsømte og kriminelle børn mellem filanatropi och stat ca 1880-1920. Holte: Socpol.

Meeuwisse, A. \& Swärd, H. (2002) Vad är ett socialt problem? I Meeuwisse, A. \& Swärd, H. (red.) Perspektiv på sociala problem. Stockholm: Natur och Kultur.

Meyerson, G. (1906) Fattigvården och det uppväxande släktet. I Berättelse över förhandlingarna vid Kongressen för Fattigvård och Folkförsäkring i Stockholm, 1906. Stockholm: CSA.

Otterström, E. (1946) Delinquency and children from bad homes. A study of their prognoses from a social point of view. Acta pediatrica, vol 33, suppl 5.

Parton, N. (1985) The Politics of Child Abuse. London: MacMillan.

Parton, N., Thorpe, D. \& Wattam, C. (1997) Child Protection. Risk and the Moral Order. London: Routledge.

Proposition 1924:150 Förslag till lag om samhällets barnavård.

Proposition 1942:20 Förslag till lag angående förändring i vissa delar av lagen om samhällets barnavård.

Proposition 1960:10 Förslag till lag om samhällets vård av barn och ungdom (Barnavairdslag).

Proposition 1979/80:1 A. Socialtjänstlagen.

Runcis, M. 1998 Steriliseringar i folkhemmet. Stockholm: Ordfront.

Sallnäs, M. (2000) Barnavårdens institutioner. Framväxt, ideologi och struktur. Stockholm: Institutionen for socialt arbete, Stockolms universitet.

Samhällets barnavård, år 1931, 1937, 1967. Stockholm: SCB.

Samhällets barnavård, år 1944, 1946, 1952, 1957. Stockholm: Socialstyrelsen.

Sarnecki, J. (1993) Ungdomsbrottslighetens omfattning, karaktär och orsaker. I SOU 1993:36,

Lundström \& Sallnäs: Klass, kön och etnicitet i den sociala barnavården 
Reaktion mot ungdomsbrott. Betänkande av Ungdomsbrottskommittén.

Schlytter, A. (1999) Kön och juridik i socialt arbete. Lund: Studentlitteratur.

SiS (2001) Årsrapport ADAD 98. Ungdomar som skrivits in på särskilda ungdomshem under 1998: bakgrund, livssituation och behandlingsbehov. Stockholm: SiS (Statens institutionsstyrelse).

Socialstyrelsen (1945) Tattarnas antal och levnadsförhållanden. Sociala meddelanden, 5, 377-392.

Socialstyrelsen (1978) Socialt arbete bland zigenare. Stockholm: Socialstyrelsen.

Socialstyrelsen (1991) Socialt arbete bland zigenare: en utvärdering av zigenarprojekt 1985-91. SoS rapport 1991:47. Stockholm: Socialstyrelsen.

Socialstyrelsen (1995) Invandrarbarn i familjhem. SoS rapport 1995:7. Stockholm: Socialstyrelsen.

Socialstyrelsen (1998) Individ- och familjeomsorgens arbete med ungdomar. Stockholm: Socialstyrelsen.

Socialstyrelsen (2002) Statistik socialtjänst, Insatser för barn och unga. Stockholm: Socialstyrelsen.

Socialvården, år 1972, 1977, 1982. Stockholm: SCB.

SOU 1942:45 Statistisk undersökning angående barnhemmen. Socialvårdskommitténs betänkande, 5.

SOU 1944:30 Undersökning och förslag angående psykisk barna- och ungdomsvård. Ungdomsvårdskommitténs betänkande, 1 .

SOU 1956:61 Ny barnavårdslag. Barnavårdskommitténs betänkande, 2 .

SOU 1974:39 Socialvården: Mål och medel. Principbetänkande.

SOU 1974:7 Barn- och ungdomsvård. Fosterbarnsutredningens betänkande.

SOU 1992:18 Tvångsvård i socialtjänsten: Ansvar och innehåll. Betänkande av IUM-utredningen om tvångsinstitutioner inom socialtjänsten.

SOU 1993:35 Reaktion mot ungdomsbrott. Betänkande av ungdomsbrottskommittén.
Sunesson, S. (1990) Utvärderingsperspektiv och organisationsanalys. Familjevården som del av socialtjänsten. I Sju perspektiv på barns och ungdoms levnadsförhållanden. Stockholm: Socialstyrelsen.

Sunesson, S. (2002) Sociala problem och samhällsbekymmer i historien. I Meeuwisse, A. och Swärd, H. (red.) Perspektiv på sociala problem. Stockholm: Natur och Kultur.

Svensson, B. (1993) Bortom all ära och redlighet: Tattarnas spel med rättvisan. Stockholm: Nordiska museets förlag.

Swift, K. (1995) Manufacturing Bad Mothers. A Critical Perspective on Child Neglect. Toronto: Toronto University Press.

Swärd, H. (1993) Mångenstädes svårt vanartad: Om problemen med det uppväxande släktet. Lund:Zenon.

Söderlind, I. (1999) Barnhem för flickor: Barn, familj och institutionsliv i Stockholm 1870-1920. Stockholm: Stockholmia förlag.

Takman, J. (1976) The Gypsies in Sweden. A sociomedical study. Stockholm: LiberFörlag.

Westberg, E. (1906) Samhällets barnavård. I Fattigvård och folkförsäkring. Skriftserie utgiven av CSA:s Fattigvårdskommitté, nr 12. Stockholm: E.J. Ekman.

Widerström, C. (1906) Fattigvården och det uppväxande släktet. I Berättelse öfver förhandlingarna vid Kongressen för Fattigvård och Folkförsäkring i Stockholm, 1906. Stockholm: CSA

Vinnerljung, B. (1996a) Fosterbarn som vuxna. Lund: Arkiv.

Vinnerljung, B. (1996b) Svensk forskning om fosterbarnsvård: en översikt. Stockholm: CUS/Liber utbildning.

Vinnerljung, B. Sallnäs, M. \& Kyhle Westermark, P. (2001) Sammanbrott vid tonårsplaceringar: Om ungdomar $i$ fosterhem och på institution. Stockholm: CUS.

Åhlund, A. (2002) Sociala problem i kulturell förklädnad. I Meeuwisse, A. och Swärd, H. (red.) Perspektiv på sociala problem. Stockholm: Natur och Kultur. 


\section{Summary}

\section{Class, gender and ethnicity in child welfare}

Class, gender and ethnicity are central themes in the contemporary analysis of social politics. Despite the obvious fact that these themes are crucial also in understanding child abuse and neglect, child welfare has traditionally not been regarded as a part of social politics or analysed as a component of the welfare state. From a historical perspective this article examines how social problems among children, young people and their families have been related to class, gender and ethnicity in official texts.

During the twentieth century one can identify three main models for recognizing problematic groups within child welfare: (1) a moralistic model (for instance, bad mothers), (2) an identification based on psychological/psychiatric categories (psychotic mothers), and (3) a model based on "objectively" defined groups (lonely mothers), who are often identified through real or assumed overrepresentation in child welfare. At the beginning of the twentieth century class and gender were mainly discussed in moral terms, while a psychological/psychiatric understanding of social problems has dominated during the rest of the century. Not until the last decades has the overrepresentation of specific groups in child welfare (poor people, single mothers, immigrants) been seen as a structural injustice. Still, child welfare and the social problems handled by its institutions are not seen as a part of social politics and the dominating welfare state institutions. In addition to an analysis of discourse, the article presents data on the quantitative relations between class, gender and ethnicity on one hand and the child welfare population on the other. 